\title{
PERBEDAAN KADAR KREATININ PADA PASIEN GAGAL GINJAL KRONIK YANG RUTIN DENGAN TIDAK RUTIN MENJALANI HEMODIALISA DI RUMAH SAKIT PERTAMINA BINTANG AMIN BANDAR LAMPUNG
}

\author{
Rima Pusita Sari ${ }^{1}$, Zulfian $^{1}$, Nia Triswanti ${ }^{3}$, Tusy Triwahyuni ${ }^{4}$ \\ ${ }^{1}$ Program Studi Kedokteran Fakultas Kedokteran Universitas Malahayati \\ ${ }^{2}$ Departemen Patologi Klinik Fakultas Kedokteran Universitas Malahayati \\ ${ }^{3}$ Departemen Biokimia Fakultas Kedokteran Universitas Malahayati \\ ${ }^{4}$ Departemen Parasitologi Fakultas Kedokteran Universitas Malahayati
}

\begin{abstract}
The Differences of Creatinine Levels in Chronic Renal Failure Patients Who Are Not Routine With Hemodialysis in The Pertamina Hospital Bintang Amin Bandar Lampung. Chronic renal failure (CRF) is a condition of progressive and irreversible damage to kidney function. Efforts to be able to reduce serum creatinine levels are of course by improving the function of the kidneys, namely by hemodialysis, routine hemodialysis therapy, namely 2 or 3 times a week, at least it has been going on for 3 months continuously. This study was aim to determine the differences in creatinine levels who routinely and not routinely undergo hemodialysis in patients with chronic kidney failure at Pertamina Bintang Amin Hospital, Bandar Lampung. The type of research used in this research is descriptive analytic with aapproach cross sectional. The number of samples in this study was 71 with technique total sampling. Test Mann Whitney gets a p-value = 0.835 where more than the value of significance is 0.05 , so it can be concluded that there is no significant difference of routine creatinine levels with no routine hemodialysis. There is no significant difference between routine and non-routine hemodialysis in patients with CRF at Pertamina Bintang Amin Hospital in Bandar Lampung.
\end{abstract}

Keywords: Chronic Kidney Failure, Creatinine, Hemodialysis

Abstrak: Perbedaan Kadar Kreatinin Pada Pasien Gagal Ginjal Kronik yang Rutin Dengan Tidak Rutin Menjalani Hemodialisa di Rumah Sakit Pertamina Bintang Amin Bandar Lampung. Gagal ginjal kronik (GGK) merupakan suatu keadaan kerusakan fungsi ginjal yang progresif dan irreversibel. Upaya agar dapat menurunkan kadar kreatinin serum tentu dengan memperbaiki fungsi dari ginjal yaitu dengan hemodialisa, terapi hemodialisa rutin yaitu dengan 2 atau 3 kali dalam seminggu, sekurang kurangnya sudah berlangsung selama 3 bulan secara continue. Tujuan penelitian ini untuk mengetahui perbedaan kadar kreatinin yang rutin dengan tidak rutin menjalani hemodialisa pada pasien gagal ginjal kronik di Rumah Sakit Pertamina Bintang Amin Bandar Lampung. Jenis penelitian yang digunakan pada penelitian ini adalah deskriptif analitik dengan pendekatan Cross Sectional. Jumlah sampel pada penelitian ini sebanyak 71 dengan teknik Total Sampling. Berdasarkan hasil uji Mann Whitney mendapatkan p-value $=0,835$ dimana lebih dari nilai kemaknaan yaitu 0,05 , sehingga dapat disimpulkan bahwa tidak terdapat perbedaan bermakna dari kadar kreatinin rutin dengan tidak rutin melakukan hemodialisa. Tidak ada perbedaan yang signifikan antara rutin dengan tidak rutin melakukan hemodialisa pada pasien GGK di Rumah Sakit Pertamina Bintang Amin Bandar Lampung.

Kata Kunci: Gagal Ginjal Kronik, Kreatinin, Hemodialisa 


\section{PENDAHULUAN}

Gagal ginjal kronik (GGK) merupakan suatu keadaan kerusakan fungsi ginjal yang progresif dan irreversibel dimana berasal dari berbagai penyakit. Ginjal memiliki berbagai peran yang sangat penting bagi tubuh, yaitu dengan mempertahankan stabilitas volume, komposisi elektrolit, dan osmolaritas cairan ekstraseluler. Selain itu, ada salah satu fungsi yang penting pada ginjal yaitu, dapat mengekskresikan produk-produk sisa metabolisme tubuh, seperti urea, asam urat, dan kreatinin (Anwar dan Ariosta, 2019).

Prevalensi Gagal Ginjal Kronik menurut Global Burden of Disease (GBD), pada tahun 2016 terdapat sebanyak 275,9 juta prevalensi GGK di seluruh dunia, terdapat 21,3 juta insiden gagal ginjal kronik, serta terdapat 1,18 juta orang meninggal karena penyakit gagal ginjal kronik. Gagal ginjal kronik merupakan penyebab kematian ke-18 di dunia pada tahun 2010 dan meningkat menjadi ke11 pada tahun 2016 (Fransisca, 2019).

Berdasarkan data dari Riset Kesehatan Dasar (Riskesdas) tahun 2018, untuk prevalensi penyakit yang berusia $\geq 15$ tahun terdapat sebanyak $2 \%$ pada tahun 2013 dan mengalami peningkatan pada tahun 2018 menjadi 3,8\% (Fransisca, 2019). Menurut Indonesian Renal Registry (IRR) pasien Gagal Ginjal Kronik pada tahun 2010 sebanyak 14.833 orang, dan pada tahun 2011 sebanyak 22.304 orang, sedangkan pada tahun 2012 mengalami peningkatan sebanyak 28.782 orang (Wakhid et al., 2018).

Untuk prevalensi pasien gagal ginjal kronik yang terdapat di Provinsi Lampung menempati urutan ke 7 , yaitu sebesar 0,3\% di Indonesia (Ujiani et al., 2018). Dan angka tersebut akan terus meningkat seiring bertambahnya usia, dengan nilai tertinggi pada kelompok usia $\geq 75$ tahun yaitu sebesar $0,6 \%$. Pada laki-laki prevalensi sebesar $(0,3 \%)$ lebih tinggi dari wanita yaitu $(0,2 \%)$, sedangkan prevalensi pada masyarakat pedesaan $(0,3 \%)$, tidak bersekolah $(0,4 \%)$, petani/nelayan/buruh $(0,3 \%)$ (Amrullah et al., 2019).

Salah satu cara yang dapat membantu dalam menegakkan diagnosis gagal ginjal yaitu dengan mengukur kadar kreatinin serum, dikarenakan senyawa ini hanya dapat diekskresikan oleh ginjal. Jika diketahui kadar kreatinin pada air seni mengalami penurunan, akan mengakibatkan penurunan laju filtrasi glomerulus (fungsi penyaringan ginjal). Penurunan laju filtrasi glomerulus pada penyakit ginjal kronik membuat kadar kreatinin dalam darah menjadi meningkat. Upaya agar dapat menurunkan kadar kreatinin serum tentu dengan memperbaiki fungsi dari ginjal yaitu dengan cuci darah (hemodialisa) guna membersihkan zatzat seperti ureum, kreatinin dan asam urat, yang dimana jika dibiarkan menumpuk dalam darah akan menjadi racun bagi tubuh (Heriansyah et al., 2019).

Pada pasien gagal ginjal yang melakukan terapi hemodialisa, membutuhkan waktu 12-15 jam untuk dialisis setiap minggunya, atau paling sedikit 3-4 jam per kali terapi (Savitri et al., 2016). Hemodialisa dilakukan dengan tujuan agar mampu mencegah terjadinya komplikasi gagal ginjal yang serius. Hemodialisa juga dapat memperbaiki abnormalitas biokimia, menyebabkan protein dan natrium dapat dikonsumsi secara bebas, serta menghilangkan kecenderungan perdarahan dan dapat membantu penyembuhan luka (Nur et al., 2018).

Pasien gagal ginjal kronik yang menjalani terapi hemodialisa berdasarkan data dari IRR pada tahun 2015 tercatat sebanyak 30.554. Proporsi penderita CKD (Chronic Kidney Disease) yang pernah atau sedang hemodialisa yang berusia $\geq 15$ tahun sebanyak 19,3\%. Sedangkan angka kematian pada pasien yang menjalani hemodialisa pada tahun 2015 tercatat sebanyak 1.243 orang (Fransisca, 2019).

Berdasarkan data BPJS (Badan Penyelenggara Jaminan Sosial) Kesehatan cabang Bandar Lampung, yang meliputi beberapa daerah seperti : 
Bandar Lampung, Lampung Selatan (Lamsel), Pesawaran, Pringsewu, dan Tanggamus, menunjukkan jumlah tindakan medis Hemodialisa pada 2015 mencapai 52.721 kasus. Sedangkan pada tahun 2018, pasien gagal ginjal kronik di RSUD Dr. H. Abdul Moeloek Provinsi Lampung sebanyak 120 orang, dengan 89 orang menjalani terapi hemodialisa. Data ini mengalami peningkatan dibanding pada tahun 2017 yaitu sebanyak 98 orang yang mengalami gagal ginjal kronik dan menjalani hemodialisa (Djamaludin et al., 2020).

\section{METODE}

Penelitian yang digunakan pada penelitian ini merupakan penelitian analitik observasional dengan pendekatan cross sectional, dimana peneliti mencari tahu perbedaan kadar kreatinin pada pasien gagal ginjal kronik yang rutin dengan tidak rutin menjalani hemodialisa. Penelitian ini dilakukan di Rumah Sakit Pertamina Bintang Amin, dan penelitian ini dilaksanakan pada bulan Oktober 2020 sampai Februari 2021. Rumah Sakit Pertamina Bintang
Amin adalah Rumah Sakit yang beralamat di Jl. Pramuka No. 27, Kemiling Permai, Kecamatan Kemiling, Kota Bandar Lampung, Lampung 35151. Populasi dalam penelitian ini adalah semua pasien Gagal Ginjal Kronik yang menjalani hemodialisa di Rumah Sakit Pertamina Bintang Amin. Sampel pada penelitian yang digunakan dalam penelitian ini adalah total sampling yaitu semua pasien Gagal Ginjal Kronik yang rutin dengan tidak rutin menjalani hemodialisa di Rumah Sakit Pertamina Bintang Amin, Bandar Lampung yang memenuhi kriteria inklusi, sampel didapatkan dari data rekam medik Rumah Sakit Pertamina Bintang Amin.

Jumlah sampel yang didapatkan pada penelitian ini yaitu sejumlah 71 sampel. Terdiri dari 37 Laki-Laki dan 34 Perempuan. Analisis data yang dilakukan pada penelitian ini meliputi analisis univariat dan analisis bivariat. Analisis bivariat dilakukan dengan uji Mann Whitney untuk mengetahui perbedaan kadar kreatinin pasien gagal ginjal kronik yang rutin dengan tidak rutin menjalani hemodialisa.

\section{HASIL}

Tabel 1. Distribusi Frekuensi Berdasarkan Usia Responden Usia Jumlah Persentase

\begin{tabular}{ccc}
\hline $\mathbf{1 5}-\mathbf{3 0}$ & 2 & $2,8 \%$ \\
$\mathbf{3 1}-\mathbf{4 0}$ & 4 & $5,6 \%$ \\
$\mathbf{4 1}-\mathbf{5 0}$ & 14 & $19,7 \%$ \\
$\mathbf{5 1}-\mathbf{6 5}$ & 51 & $71,8 \%$ \\
& & \\
\hline Total & $\mathbf{7 1}$ & $\mathbf{1 0 0} \%$ \\
\hline
\end{tabular}

Berdasarkan tabel 1 diketahui bahwa distribusi frekuensi karakteristik pasien berdasarkan usia, didapatkan pada kelompok usia 15 - 30 tahun berjumlah 2 pasien $(2,8 \%)$, pada kelompok usia 31 - 40 tahun berjumlah 4 pasien $(5,6 \%)$, untuk kelompok usia
41 - 50 tahun berjumlah 14 pasien $(19,7 \%)$, sedangkan pada kelompok usia 51 - 65 tahun berjumlah 51 pasien $(71,8 \%)$. Sehingga dapat diketahui bahwa jumlah responden terbanyak yaitu pada kelompok usia 50 - 65 tahun dengan jumlah 51 pasien $(71,8 \%)$. 
Tabel 2. Distribusi Frekuensi Berdasarkan Jenis Kelamin Responden

\begin{tabular}{ccc} 
Jenis Kelamin & Jumlah & Persentase \\
\hline Laki-Laki & 37 & $52,1 \%$ \\
Perempuan & 34 & $47,9 \%$ \\
\hline Total & $\mathbf{7 1}$ & $\mathbf{1 0 0 \%}$ \\
\hline
\end{tabular}

Berdasarkan tabel 2 di atas, diketahui bahwa pasien yang menjalani hemodialisa dengan jenis kelamin lakilaki berjumlah 37 pasien $(52,1 \%)$, sedangkan pada wanita yang menjalani hemodialisa berjumlah 34 pasien
$(47,9 \%)$. Dengan ini dapat disimpulkan bahwa sebagian besar pasien yang menjalani hemodialisa berdasarkan jenis kelamin adalah laki-laki, yaitu 37 pasien $(52,1 \%)$.

Tabel 3. Distribusi Frekuensi Berdasarkan Rutin dengan Tidak Rutin Responden

\begin{tabular}{ccc} 
Hemodialisa & Jumlah & Persentase \\
\hline Rutin & 45 & \\
Tidak Rutin & 26 & $63,4 \%$ \\
& & $36,6 \%$ \\
\hline Total & $\mathbf{7 1}$ & $\mathbf{1 0 0} \%$ \\
\hline
\end{tabular}

Berdasarkan tabel 3, distribusi frekuensi responden berdasarkan rutin dengan tidak responden menjalani hemodialisa menunjukkan bahwa pasien yang rutin menjalani hemodialisa berjumlah 45 pasien $(63,4 \%)$ responden, sedangkan pada pasien yang tidak rutin menjalani hemodialisa berjumlah 26 pasien $(36,6 \%)$. Menurut hasil tersebut menunjukkan sebagian besar pasien yang menjalani hemodialisa adalah pasien yang rutin yaitu berjumlah 45 orang $(63,4 \%)$.

Tabel 4. Distribusi Frekuensi Rerata Kadar Kreatinin Responden

\begin{tabular}{ccc}
\hline Variabel & Min-Max $(\mathbf{m g} / \mathbf{d L})$ & Mean $\mathbf{\text { S SD }}$ \\
\hline Kreatinin Rutin & $6.0-18.4$ & $11.3 \pm 33.64$ \\
Kreatinin Tidak Rutin & $5.4-36.7$ & $12.0 \pm 66.84$ \\
\hline
\end{tabular}

Berdasarkan tabel 4, memperlihatkan bahwa nilai kadar kreatinin rutin pada pasien gagal ginjal kronik yang menjalani hemodialisa dengan nilai minimum kadar kreatinin rutin 6.0, sedangkan untuk nilai maksimum kadar kreatinin rutin didapatkan 18.4, untuk rerata kadar
, kreatinin rutin hemodialisa didapatkan nilai 11.3. Sedangkan untuk kadar kreatinin pada pasien gagal ginjal kronik yang tidak rutin menjalani hemodialisa didapatkan nilai minimum 5.4, nilai maksimum didapatkan 36.7, dan rerata kadar kreatinin tidak rutin hemodialisa didapatkan 12.0. 
Tabel 5. Uji Perbedaan Kadar Kreatinin Rutin Dengan Tidak Rutin Hemodialisa pada Responden

\begin{tabular}{ccccc}
\hline Kadar Kreatinin & N & Mean Rank & Sum of Rank & p-value \\
\hline Rutin & 45 & 36.39 & 1637.50 & 0.835 \\
Tidak Rutin & 26 & 35.33 & 918.50 & \\
\hline
\end{tabular}

Tabel 5 uji perbedaan kadar kreatinin rutin dengan tidak rutin menjalani hemodialisa, menggunakan uji Mann Whitney, didapatkan mean rank (peringkat rata-rata) kadar kreatinin pada pasien yang rutin menjalani hemodialisa lebih besar dari pada pasien yang tidak rutin, dengan ini menunjukkan bahwa pasien yang rutin menjalani hemodialisa cenderung dapat mempengaruhi kadar kreatinin dari pada pasien yang tidak rutin menjalani hemodialisa. Dengan ini dapat dikatakan bahwa rutin melakukan hemodialisa lebih efektif dapat menurunkan kadar kreatinin dari pada pasien yang tidak rutin menjalani hemodialisa. Pada uji ini diperoleh hasil $p$-value $=0,835$, dimana diketahui bahwa $p$-value uji Mann Whitney tersebut lebih dari nilai kemaknaan yaitu 0,05 , yang mana dapat disimpulkan bahwa tidak terdapat perbedaan dari kadar kreatinin rutin dengan tidak rutin menjalani hemodialisa.

\section{PEMBAHASAN}

Berdasarkan pada hasil dari distribusi frekuensi berdasarkan usia terlihat perbandingan jumlah kelompok usia pasien Gagal Ginjal Kronik dengan usia 50 - 65 tahun jauh lebih tinggi dari pada kelompok usia dibawah 50 tahun, terutama pada kelompok usia 15 - 30 tahun, dimana jumlah pasien sangat rendah yaitu berjumlah 2 responden, hal tersebut dikarenakan semakin bertambah usia semakin berkurang fungsi ginjal dan berhubungan dengan penurunan kecepatan ekskresi glomerulus dan memburuknya fungsi tubulus (Pranandari dan Supadmi, 2015). Hasil pada penelitian ini juga sejalan dengan penelitian yang dilakukan oleh Sugiarti pada tahun 2018 di RS Dr Tjitrowardojo Purworejo, dimana pada penelitian tersebut menyimpulkan bahwa gagal ginjal kronis lebih banyak dialami pasien yang berusia diatas 40 tahun (Sugiarti, 2018).

Dilihat dari hasil distribusi frekuensi berdasarkan jenis kelamin terlihat perbedaan yang cukup signifikan antara laki-laki dan perempuan, Secara klinik laki laki mempunyai risiko mengalami gagal ginjal kronik 2 kali lebih besar dari pada perempuan. Hal ini dimungkinkan karena perempuan lebih memperhatikan kesehatan dan menjaga pola hidup sehat dibandingkan laki-laki, sehingga laki-laki lebih mudah terkena gagal ginjal kronik dibandingkan perempuan. Perempuan lebih patuh dibandingkan laki-laki dalam menggunakan obat karena perempuan lebih dapat menjaga diri mereka sendiri serta bisa mengatur tentang pemakaian obat (Pranandari dan Supadmi, 2015).

Hasil penelitian ini sejalan dengan penelitian yang dilakukan oleh Ipo pada tahun 2016, pada pasien gagal ginjal kronis yang melakukan hemodialisa di Di Rumah Sakit Umum Daerah Raden Mattaher Jambi yang menunjukkan hal yang sama, peneliti menunjukkan bahwa laki-laki lebih banyak daripada perempuan. Prevalensi laki-laki lebih besar dari pada perempuan karena aktivitas laki-laki lebih banyak (Ipo, 2016).

Berdasarkan tabel 3 terlihat perbedaan yang signifikan antara pasien yang rutin menjalani hemodialisa dengan pasien yang tidak rutin menjalani hemodialisa, hal ini diduga karena hemodialisa adalah suatu terapi pengganti fungsi ginjal pada pasien yang menderita gagal ginjal, sehingga pasien lebih patuh untuk rutin melakukan hemodialisa. Dalam memperbaiki fungsi ginjal ini perlu dilakukan cuci darah (hemodialisa) untuk mengganti fungsi utama ginjal yaitu membersihkan darah dari sisa-sisa hasil metabolisme tubuh yang berada di dalam darah (Indrasari, 2015). 
Pada penelitian ini terdapat beberapa perbedaan kadar kreatinin pada pasien gagal ginjal kronik yang rutin dengan tidak rutin menjalani hemodialisa, dimana kadar kreatinin tertinggi terdapat pada pasien yang tidak rutin menjalani hemodialisa, walaupun untuk perbedaan kadarnya sendiri tidak terlihat dengan signifikan. Namun pada penelitian ini sendiri memiliki beberapa keterbatasan penelitian, seperti keterbatasan data rekam medik yang memuat data kadar kreatinin, dikarenakan tidak selalu pasien yang melakukan hemodialisa akan melakukan tes untuk melihat kadar kreatinin, hal ini bisa menjadi penyebab hasil kadar kreatinin tidak terdapat perbedaan yang bermakna.

Pasien yang melakukan

hemodialisa secara rutin di Rumah Sakit Pertamina Bintang Amin juga memiliki jumlah lebih besar dibandingkan pasien yang tidak rutin melakukan hemodialisa, hal ini diduga menjadi penyebab kadar kreatinin pasien yang rutin dengan tidak rutin menjalani hemodialisa menunjukan perbedaan yang signifikan. Hasil penelitian ini sejalan dengan penelitian yang dilakukan oleh Indrasari tahun 2015, dimana pada hasil penelitian tersebut menunjukan bahwa kadar kreatinin dengan nilai $p>0,66$ ( $p$ $<0,05)$, sehingga disimpulkan bahwa kadar kreatinin pada pasien gagal ginjal kronik berdasarkan lama menjalani terapi hemodialisa di RS PKU Muhammadiyah Yogyakarta berbeda tidak bermakna.

Namun hal ini bertentangan dengan penelitian yang dilakukan oleh Nurmalasari (2018), dimana pada penelitian ini menunjukkan hasil ratarata kadar kreatinin sebelum hemodialisa lebih tinggi $4,4196 \mathrm{mg} / \mathrm{dL}$ dari kadar kreatinin sesudah hemodialisis. Dan didapatkan hasil uji TTest dengan signifikansi sebesar 0,000 untuk kreatinin. Hasil ini menunjukkan bahwa terdapat perbedaan yang bermakna antara kadar kreatinin sebelum dan sesudah hemodialisis.

\section{KESIMPULAN}

Berdasarkan hasil uji statistik maka dapat diambil kesimpulan bahwa tidak terdapat perbedaan pada pasien gagal ginjal kronik yang rutin dengan tidak rutin menjalani hemodialisa.

\section{SARAN}

Bagi peneliti selanjutnya diharapkan dapat meneliti lebih lanjut dengan desain rancangan penelitian yang lebih baik, dengan sampel yang lebih banyak dan bervariasi untuk membuktikan adanya perbedaan kadar kreatinin pada pasien yang rutin dengan tidak rutin menjalani hemodialisa.

Pada masyarakat khususnya pasien Gagal Ginjal Kronik, hendaknya hasil penelitian ini dapat memberikan informasi dan masukan kepada masyarakat mengenai penyakit gagal ginjal kronik dan kadar kreatinin rutin dengan tidak rutin menjalani hemodialisa. Dan agar pasien lebih memperhatikan kesehatan dan asupan makanan yang dikonsumsi.

Bagi petugas kesehatan agar memberikan pendidikan kesehatan kepada masyarakat tentang upaya untuk mencegah penyakit gagal ginjal kronik dengan mengedukasi dan memberitahukan factor-faktor resiko terjadinya gagal ginjal kronik.

Bagi institusi pendidikan terkait, diharapkan hasil penelitian ini dapat menjadi bahan atau materi pembelajaran yang baik kalangan mahasiswa dan Pendidikan sarjana maupun profesi.

\section{DAFTAR PUSTAKA}

Amrullah, F.M., Kurniati, I., Cania, E., Tjiptaningrum, A., Ayu, P.R. dan Anggarini, D.I. (2019). Perbedaan Jumlah Neutrofil Pre dan Post Hemodialisis Pasien Penyakit Ginjal Kronik (PGK) di RSUD Dr. H. Abdul Moeloek Provinsi Lampung. MEDULA, Medical Profession Journal of Lampung University 8(2): 19-22.

Anwar, S. dan Ariosta, A. (2019). Perbedaan Kadar Ureum, Natrium, Kalium dan Klorida Pra dan Pasca Hemodialisa Pada 
Pasien Dengan Penyakit Ginjal Kronik. Intisari Sains Medis 10(1): 223-226.

Djamaludin, D., Chrisanto, E.Y., dan Wahyuni, M.S. (2020). Pengaruh Latihan Fisik Terhadap Penurunan Fatigue Pada Pasien Gagal Ginjal Kronik Yang Menjalani Hemodialisa Di RSUD Dr. H. Abdul Moeloek Provinsi Lampung. Malahayati Nursing Journal 2(4): 667-676.

Fransisca, D. (2019). Hubungan Antara Lama Hemodialisis Dengan Fungsi Kognitif Pasien Gagal Ginjal Kronik Menggunakan Montreal Cognitive Assesment Versi Indonesia (Moca-Ina) di Ruang Hemodialisa, RSUD Pasar Rebo. [Skripsi]. Jakarta: Universitas Pembangunan Nasional Veteran.

Heriansyah, H., Humaedi, A., dan Widada, N.S. (2019). Gambaran Ureum Dan Kreatinin Pada Pasien Gagal Ginjal Kronis Di Rsud Karawang. Binawan Student Journal 1(1): 8-14.

Indrasari, D. N. 2015. Perbedaan Kadar Ureum dan Kreatinin pada Pasien Gagal Ginjal Kronik Berdasarkan Lama Menjalani Terapi Hemodialisa di RS PKU Muhammadiyah Yogyakarta. [Skripsi]. Yogyakarta: STIKES 'Aisyiyah Yogyakarta.

Ipo, A., Aryani, T. dan Suri, M. (2018). Hubungan Jenis Kelamin Dan Frekuensi Hemodialisa Dengan Kualitas Hidup Pasien Gagal Ginjal Kronik Yang Menjalani Hemodialisa Di Rumah Sakit Umum Daerah Raden Mattaher Jambi. Jurnal Akademika Baiturrahim Jambi 5(2): 46-55.

Nurmalasari, M.A. (2018). Perbandingan Kadar Hemoglobin dan Kadar Kreatinin Sebelum dan Sesudah Hemodialisis pada Pasien Gagal Ginjal Kronik. [Disertasi]. Surabaya: Universitas Airlangga.

Nur, M., Anggunan, A. dan Wulandari, P.D.W.D. (2018). Hubungan Kadar Asam Urat dengan Kadar Kreatinin pada Pasien Gagal
Ginjal Kronik yang Menjalani Hemodialisa di Rumah Sakit Pertamina Bintang Amin Bandar Lampung Tahun 2016. Jurnal IImu Kedokteran dan Kesehatan $5(4)$.

Pranandari, R. dan Supadmi, W. (2015). Faktor risiko gagal ginjal kronik di unit hemodialisis RSUD Wates Kulon Progo. Majalah Farmaseutik 11(2):316-320.

Savitri, E.R.E. (2016). Hubungan Lama Terapi Hemodialisis dan Indeks Massa Tubuh dengan Kualitas Hidup Pasien Gagal Ginjal Kronis yang Menjalani Terapi Hemodialisis di Unit Hemodialisa Rumah Sakit Umum Daerah Abdul Wahab Sjahranie Kota Samarinda Tahun 2016. [Skripsi]. Samarinda: STIKES Muhammadiyah.

Sugiarti, W., Makiyah, S.N.N. dan Khoiriyati, A. (2018). Pengaruh Intradialytic Exercise Terhadap Penurunan Nyeri Pasien Hemodialisa Rutin Di Unit Hemodialisa Rsud Dr. Tjitrowardojo Purworejo. The Shine Cahaya Dunia Ners 3(1).

Ujiani, S., Tuntun, M., dan Hasibuan, T.M.R. (2018). Perbedaan Nilai PDW, MPV, dan Jumlah Trombosit Pada Pre dan Post Hemodialisa Pasien Gagal Ginjal Kronik. Jurnal Analis Kesehatan 7(1): 649-656.

Wakhid, A., Kamsidi, K. dan Widodo, G.G. (2019). Gambaran Tingkat Depresi Pasien Gagal Ginjal Kronik yang Menjalani Hemodialisis. Jurnal Keperawatan Jiwa 6(1): 25-28. 